\title{
Pengembangan Industri Kreatif di Panti Asuhan Miftahunnajah Banguntapan Bantul Yogyakarta Berupa Pendampingan Pemasaran Produk Kreatif dari Bahan Limbah Konveksi Kain Perca
}

\author{
Uyuunul Mauidzoh \\ Program Studi Teknik Industri \\ Sekolah Tinggi Teknologi Adisutjipto \\ J1. Janti Blok R Lanud Adisutjipto Yogyakarta \\ yun_mdz@yahoo.com
}

\begin{abstract}
Miftahunnajah Wonocatur Banguntapan orphanage can be developed to be more economically independent by not always relying on donated donations. The environment around the orphanage is widely available resources that can be raised to be developed in the form of creative industries. One of the existing resources is the presence of waste in the form of patchwork patchwork. Creativity of santri orphanage Miftahunnajah this needs to be developed in order to capture opportunities that exist in the vicinity, one of them by utilizing a patchwork into a creative product and can be marketed so as to support the economy of the orphanage and become an economic self-sufficient Orphanage. Therefore, in the dedication of the Community Activities Academic Year 2017/2018, the executor of dedication to mentoring Miftahumnajah Orphanage in marketing the creative products from the waste material of the patchwork so that it can support the orphanage economy and become an economically self-sustaining Orphanage. The steps undertaken in the Community Service activities are as follows: 1) Conducting a survey to find out the condition of the Orphanage Miftahunnajah Wonocatur Banguntapan, 2) Conduct a worthy collection of creative industries to be accompanied, 3) Conducting business assistance in the form of creative product marketing guidance of the patchwork waste material. The result of this community service activity is children at Orphanage Miftahunnajah can make promotion media in social media (facebook fan page) and can make simple advertisement using Coral draw software
\end{abstract}

Keywords : creative industry; marketing

\begin{abstract}
Abstrak
Panti Asuhan Miftahunnajah Wonocatur Banguntapan dapat dikembangkan agar lebih mandiri secara ekonomi dengan tidak selalu menggantungkan pada sumbangan donator yang ada. Lingkungan disekitar panti asuhan banyak tersedia sumber daya yang bisa diangkat untuk dikembangkan dalam bentuk industri kreatif. Salah satu sumber daya yang ada adalah adanya limbah konveksi berupa kain perca. Kreatifitas para santri panti asuhan Miftahunnajah ini perlu dikembangkan agar bisa menangkap peluang yang ada di sekitarnya, salah satunya dengan memanfaatkan kain perca menjadi produk kreatif dan bisa dipasarkan sehingga dapat mendukung perekenomian panti asuhan dan menjadi Panti Asuhan yang mandiri secara ekonomi. Oleh karena itu dalam kegiatan Pengabdian pada Masyarakat Tahun Akademik 2017/2018 ini, pelaksana pengabdian melakukan pendampingan untuk membimbing Panti Asuhan Miftahunnajah dalam memasarkan produk kreatif dari bahan limbah kain perca sehingga dapat mendukung perekenomian panti asuhan dan menjadi Panti Asuhan yang mandiri secara ekonomi. Langkah-langkah yang dilakukan dalam kegiatan Pengabdian pada Masyarakat ini adalah sebagai berikut : 1) Melakukan survey untuk mengetahui kondisi Panti Asuhan Miftahunnajah Wonocatur Banguntapan, 2) Melakukan
\end{abstract}


pendataan industri kreatif yang layak untuk dilakukan pendampingan, 3) Melakukan pendampingan usaha berupa bimbingan pemasaran produk kreatif dari bahan limbah kain perca. Hasil dari kegiatan pengabdian kepada masyarakat ini adalah anak-anak di Panti Asuhan Miftahunnajah dapat membuat media promosi di media sosial (Fan Page Facebook) serta dapat membuat iklan sederhana menggunakan Software Coral Draw.

Kata Kunci : industri kreatif; pemasaran

\section{Latar Belakang Masalah}

Ekonomi kreatif adalah gagasan baru sistem ekonomi yang menempatkan informasi dan kreativitas manusia sebagai faktor produksi yang paling utama. Ide merupakan barang mahal dalam ekonomi kreatif, karena ide-ide yang kreatif inilah yang akan mendorong terciptanya inovasi-inovasi yang kemudian menjadi solusi baru dan produk baru, dimana ini merupakan jawaban selama ini atas masalah minimnya kualitas produk yang sesuai dengan kebutuhan pasar. Ekonomi kreatif akan menggeser produk-produk hasil industri konvensional dan memberikan solusi baru yang lebih tepat untuk kebutuhan pasar. Untuk itu perlu ditumbuhkan industri kreatif yang ada di masyarakat sehingga bisa meningkatkan kesejahteraan masyarakat. Dengan tumbuhnya kreatifitas masyarakat ini akan bisa menggerakkan perekonomian masyarakat. Dengan demikian akan tercipta suatu masyarakat yang mandiri,

Panti asuhan Miftahunnajah Wonocatur Bantul memiliki peluang dalam mengembangkan industri kreatif, sehingga menjadi masyarakat yang mandiri secara ekonomi. Salah satu industri kreatif yang dapat dikembangkan adalah industri kerajinan dengan membuat produk dari kain perca. Kain perca merupakan limbah dari industri konveksi yang ada di Yogyakarta. Solusi untuk mengatasi permasalahan kurangnya kreatifitas para santri di Panti Asuhan Miftahunnajah adalah dengan memberikan pendampingan bimbingan usaha memanfaatkan limbah konvensi kain perca menjadi produk yang dapat dipasarkan sehingga dapat mendukung perekenomian panti asuhan dan menjadi Panti Asuhan yang mandiri secara ekonomi.

\section{Metodologi Pelaksanaan}

Langkah-langkah yang dilakukan dalam kegiatan Pengabdian pada Masyarakat ini adalah sebagai berikut :

a. Melakukan survey untuk mengetahui kondisi Panti Asuhan Miftahunnajah di wilayah Wonocatur Banguntapan.

b. Melakukan pendataan industri kreatif yang layak untuk dikembangkan.

c. Melakukan pendampingan usaha berupa bimbingan pemasaran produk kreatif dari bahan limbah konveksi berupa kain perca.

\section{Hasil dan Pembahasan}

Kegiatan pelaksanaan Pengabdian Pada Masyarakat untuk Tahun Akademik 2017/2018 ini diwujudkan dalam bentuk pendampingan usaha berupa bimbingan pemasaran produk kreatif dari bahan limbah konveksi berupa kain perca, sehingga para santri di Panti asuhan Miftahunnajah Wonocatur Banguntapan dapat memasarkan produk assesoris seperti bros, bando, ikat rambut dari bahan limbah konveksi (kain perca). Dari kegiatan ini, para santri dapat membuat media pemasaran di media sosial 
(Fan Page Facebook) serta dapat membuat iklan dengan menggunakan Software Corel Draw.

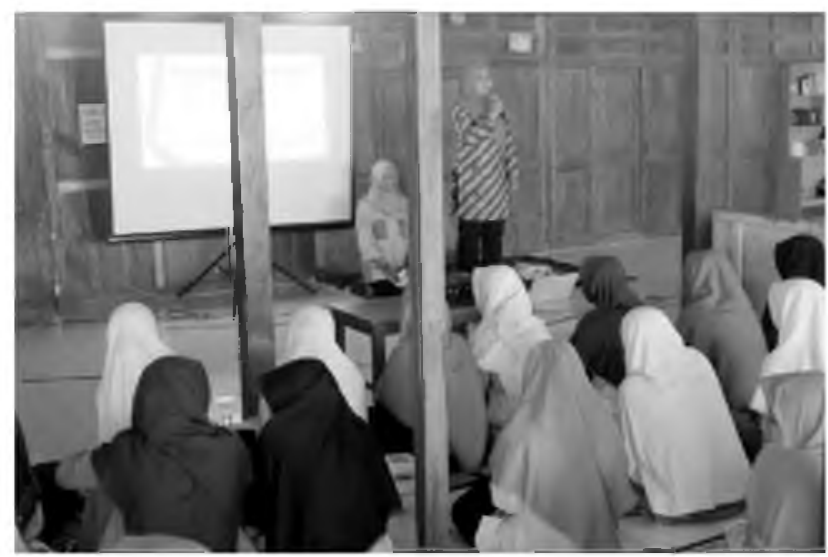

Gambar 1. Bimbingan Pemasaran Produk dari Kain Perca

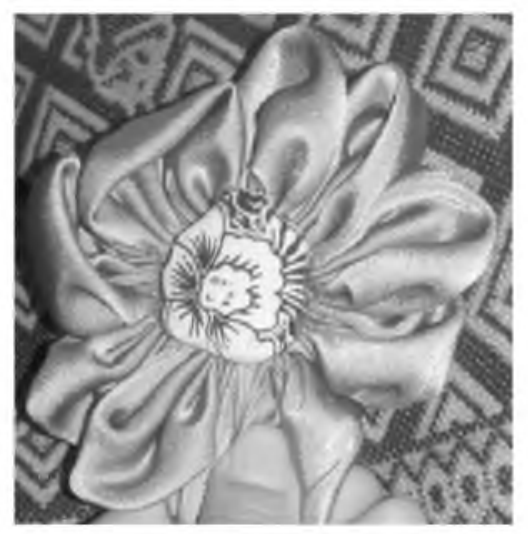

Gambar 2. Contoh produk dari kain perca

\section{Kesimpulan}

Berdasarkan pada pelaksanaan program Pengabdian Pada Masyarakat T.A. 2017/2018, peserta pendampingan usaha bimbingan pemasaran produk aksesoris dari kain perca sangat antusias mengikuti kegiatan in dan mereka sudah dapat membuat media promosi di media sosial (Fan Page Faceebook) serta dapat membuat iklan dengan menggunakan Software Corel Draw.

\section{Daftar Pustaka}

[1] Kotler, 2009, Manajemen Pemasaran,Edisi 13, Erlangga

[2] Zimmerer, Scarborough, 2008, Kewirausahaan: Manajemen Usaha Kecil, Salemba Empat, Jakarta 
